\title{
Invasive Malignant Thymoma
}

National Cancer Institute

\section{Source}

National Cancer Institute. Invasive Malignant Thymoma. NCI Thesaurus. Code C7904.

A malignant thymoma that extends beyond the capsule and infiltrates the surrounding tissues. 